\title{
An evaluation of fluorescence techniques for measuring DNA and RNA in marine microorganisms
}

\author{
Calvin W. Mordy, David J. Carlson \\ College of Oceanography, Oregon State University Corvallis, Oregon 97331-5503, USA
}

\begin{abstract}
The DNA-specific fluorochrome Hoechst 33258 (H33258) and the DNA- and RNAsensitive fluorochrome ethidium homodimer (EthDi) were used to detect $\mathrm{ng} \mathrm{ml} \mathrm{ml}^{-1}$ concentrations of nucleic acids in marine microorganisms. These fluorochromes were 4 to 5 times more sensitive to DNA than ethidium bromide, and their use significantly reduced the amount of sample necessary to measure nucleic acids in seawater. Both fluorochromes responded in a linear fashion to standard DNA, but the response of EthDi to RNA was non-linear for the majority of RNA types tested. Chlorophyll a quenched fluorescence of both fluorochromes, especially of EthDi, at concentrations that could be encountered in sample homogenates. Two techniques were used to measure DNA and RNA on cultures of marine bacteria and phytoplankton; H33258 and EthDi together (double fluorochrome technique), and EthDi with and without RNase (RNase digestion method). In general, DNA and RNA were measured equally well using either technique; discrepancies between techniques were attributed to EthDi quenching or the specificity of $\mathrm{H} 33258$ for DNA rich in dA-dT base pairs. The double fluorochrome technique was used to determine depth profiles of DNA and RNA/DNA in size-fractionated natural seawater These properties showed significant changes between the surface and $100 \mathrm{~m}$ and may be related to changes in biomass or metabolic activity. Although consideration must be given to the RNA standard used and the presence of naturally occuring pigments, the combination of H33258 and EthDi can provide a rapid and sensitive measure of nucleic acids in seawater without the use of nucleases.
\end{abstract}

\section{INTRODUCTION}

To understand plankton abundance and dynamics, some investigators have used fluorescent dyes to measure particulate DNA (Takahashi et al. 1974, Paul \& Carlson 1984, Paul et al. 1985). To obtain additional information, especially about metabolic activity, fluorometric and absorbance measurements of RNA have also been made (Takahashi et al. 1974, Dortch et al. 1983, Moyer \& Morita 1989). However, previous methods to measure RNA were relatively insensitive, or too elaborate for rapid analysis (Randerath \& Randerath 1969, Thoresen et al. 1983, Iturriaga et al. 1984). Some fluorochromes, such as ethidium bromide (EthBr), react with nucleic acids generally and thus require a digestion step to distinguish RNA from DNA. A dimer of EthBr, ethidium homodimer (EthDi), has been developed (Gaugain et al. 1978a) with much improved sensitivity for DNA and RNA (Markovits et al. 1979, Reinhardt et al. 1982, Moyer et al. 1990). We investigated the use of this fluorochrome with a diges- tion step or in conjunction with the DNA-specific fluorochrome Hoechst 33258 (H33258) to measure DNA and RNA in marine microorganisms. The results suggest that the combination of $\mathrm{H} 33258$ and EthDi provides a sensitive method to measure nucleic acids in marine microorganisms.

\section{MATERIALS AND METHODS}

Emission scans with DNA were measured for each fluorochrome separately and with the 2 fluorochromes combined to determine if significant interference occured between the fluorochromes. The DNA response of $\mathrm{H} 33258$ and EthDi was also compared to the response of EthBr, a fluorochrome often used to measure nucleic acids. Several types and preparations of RNA were measured with EthDi to determine an appropriate RNA standard. The response of H33258 and EthDi with DNA was measured in the presence of standard chlorophyll a (chl a), which is known to com- 
plicate EthBr measurements (Thoresen et al. 1983). The double fluorochrome method was used to measure nucleic acids in cultures of marine bacteria at different stages of starvation-survival and in batch cultures of phytoplankton. The results were compared to measurements made using an RNase digestion method which used EthDi on subsamples with and without RNase (Thoresen et al. 1983). Natural seawater samples were also measured for DNA and RNA using the double fluorochrome method. A technique similar to the double fluorochrome method but using $\mathrm{H} 33258$ with EthBr to measure DNA and RNA in fish larvae has been described by Clemmesen (1988).

Chemicals. The nucleic acid stains used were Hoechst 33258 (H33258-Calbiochem, San Diego, CA, USA), ethidium homodimer (EthDi-Molecular Probes, Eugene, OR, USA) and ethidium bromide (EthBr). The standard nucleic acids used were calf thymus DNA type I (Sigma, St. Louis, MO, USA), bakers yeast RNA type III and type XI (Sigma), Escherichia coli strain B RNA (Calbiochem), E. coli strain W transfer RNA (tRNA) and ribosomal RNA (rRNA) (Sigma), and bovine liver rRNA (Sigma). Anacystis nidulans chl a was from Sigma, and RNase (DNase-free), heparin and Triton X-100 were from Calbiochem.

Solutions and standards. All glassware used was precombusted at $480^{\circ} \mathrm{C}$ to remove any nuclease contamination. The buffer solutions used were $0.05 \mathrm{M}$ Tris, $0.05 \mathrm{M} \mathrm{NaCl}_{1} \mathrm{pH} 7.3$ (TN buffer) or $0.05 \mathrm{M}$ Tris, $0.05 \mathrm{M}$ $\mathrm{NaCl}, 0.001 \mathrm{M}$ EDTA, $1 \% \mathrm{NaN}_{3}, \mathrm{pH} 7.3$ (TNEA buffer). Except where noted, TNEA buffer was used with cultures and TN buffer for natural samples. Primary stock solutions of $\mathrm{H} 33258(0.19 \mathrm{mM})$ were made in distilled, deionized water. Working stock solutions of H33258 (3.8 $\mu \mathrm{M})$ were made fresh daily by diluting the primary stock solution in buffer. Primary stock solutions of EthDi $(47 \mu \mathrm{M})$ and $\mathrm{EthBr}(74 \mu \mathrm{M})$ were made in buffer containing $1 \%$ methanol. Concentrations of EthDi and EthBr working stock solutions were $12 \mu \mathrm{M}$. All solutions were stored in the dark at $4{ }^{\circ} \mathrm{C}$. Under these conditions, EthDi was stable for months.

The concentrations of all nucleic acid standard stock solutions were determined gravimetrically, except for the rRNAs in which the concentrations were determined from the absorbance to weight conversions provided by Sigma. Stack solutions of standard DNA and Escherichia coli strain B RNA were made in TN buffer and portions of these stock solutions were stored frozen in sterile scintillation vials. Stock solutions of other RNA standards were made in TNEA buffer and used immediately. Standards were measured by diluting the standard stock solutions with buffer to concentrations representative of the culture and sample homogenates. Each day that samples or cultures were measured for nucleic acids, the fluorescence response of 3 standards was also determined; standard DNA with H33258, standard DNA with EthDi, and E. coli strain B RNA with EthDi. Previous experiments showed that these standards had fluorescence responses independent of sonication and of treatments with Triton X-100 or heparin. Stock solutions of Triton X-100 were $0.5 \%(\mathrm{v} / \mathrm{v})$ in buffer. RNase and heparin stock solutions were made fresh daily in buffer at 10 and $5 \mathrm{mg} \mathrm{ml}^{-1}$ respectively. Solutions of chl a were made by dissolving and diluting chl a in methanol, and were used immediately.

Cultures. A gram-negative bacterial rod (OR5-88) was isolated from a seawater sample taken off the Oregon coast $\left(44^{\circ} 39.0^{\prime} \mathrm{N}, 125^{\circ} 59.6^{\prime} \mathrm{W}\right)$ in September 1988 from $5 \mathrm{~m}$ using the bow-pump of the RV 'Wecoma' during cruise W8808. OR5-88 was maintained in batch culture on a rotary shaker at $11^{\circ} \mathrm{C}$ using SLX medium (Moyer \& Morita 1989). Two chemostats were assembled according to Moyer \& Morita (1989). inoculated with $\log$ phase cells, and maintained at $11^{\circ} \mathrm{C}$ with SLX medium. Constant growth was assumed after $4 \mathrm{l}$ passed through the chemostats (chemostat volume $=345 \mathrm{ml}$ ). Doubling rates, estimated from chemostat dilution rates, were $0.5 \mathrm{~d}^{-1}$ and $0.0201 \mathrm{~h}^{-1}$ for replicate chemostats. Cells from each chemostat were harvested by centrifugation, rinsed 3 times in artificial seawater and starved separately in the dark at $11^{\circ} \mathrm{C}$ in aged seawater. The aged seawater had been collected from $2000 \mathrm{~m}$ and stored in the dark for 2 yr before use. Replicate measurements of DNA and RNA were made on each starved culture on 9 different days of starvation up to $121 \mathrm{~d}$.

Phytoplankton cultures were provided by $T$. Cowles and S. Neuer (Oregon State University) and included Gymnodinium simplex, Thalassiosira weissflogii, Chlorella vulgaris, Asterionella japonica, Chaetoceros sp., and BB1, an unclassified algae from Station P isolated by B. Booth (University of Washington). Phytoplankton cells were grown in batch culture (IMR/4 media, Eppley et al. 1967) under continuous fluorescent light from 8 Sylvania $60 \mathrm{~W}$ bulbs at $12^{\circ} \mathrm{C}$. Replicates of each culture were measured for DNA and RNA as discussed below Because these cultures were only used to compare techniques of measuring nucleic acids, samples were used without regard to the stage of growth of the cultures.

Treatments. Cultured cells ( 1 to $6 \mathrm{ml}$ ) were pressurefiltered on $0.2 \mu \mathrm{m}$ (bacteria cultures) or $1.0 \mu \mathrm{m}$ (phytoplankton cultures) Nuclepore filters at $<7 \mathrm{psi}\left(4.7 \times 10^{4}\right.$ $\mathrm{Pa}$ ). All filters, including filters for $0.2 \mu \mathrm{m}$ or $1.0 \mu \mathrm{m}$ blanks, were pre-rinsed with $15 \mathrm{ml}$ of buffer. Treatments of cell homogenates and blanks were identical. The filters were placed in individual $15 \mathrm{ml}$ polypropylene centrifuge tubes on ice containing $8.0 \mathrm{ml}$ buffer and $40 \mu \mathrm{l}$ of Triton X-100. Cells on Nuclepore filters were disrupted on ice with pulsed sonication for $90 \mathrm{~s}$ using a 
Branson W-350 power source with a Heat Systems 1/8" $(0.32 \mathrm{~mm})$ microtip assembly at 5.0 output with $60 \%$ duty (Paul \& Myers 1982). Heparin was added ( $40 \mu \mathrm{l}$ ) to phytoplankton homogenates to displace nucleohistones which are known to block DNA fluorochrome binding sites in eukaryotes (Karsten \& Wollenberger 1977. Bonaly et al. 1987). RNA was digested in a $2.6 \mathrm{ml}$ homogenate subsample by adding $5 \mu$ of RNase. Homogenates with heparin and subsamples with RNase were incubated at $40^{\circ} \mathrm{C}$ for $20 \mathrm{~min}$. Homogenate subsamples digested with RNase were measured with EthDi while homogenates without added RNase were measured with EthDi and H33258 as discussed below.

Fluorescence measurements. Fluorescence measurements of standards, blanks, and homogenates were identical and non-sequential to prevent any bias during handling. Fluorescence was measured in a $3 \mathrm{ml}$ quartz cell by adding $100 \mu \mathrm{l}$ of $\mathrm{H} 33258$, EthDi, or EthBr working stock solution to $2.4 \mathrm{ml}$ of standard, blank, or homogenate, and mixing for $30 \mathrm{~s}$ to ensure complete reaction. Standard chl a was measured by adding 100 $\mu \mathrm{l}$ of chl a solution to a cuvette containing $2.4 \mathrm{ml}$ of either $315 \mathrm{ng} \mathrm{ml}^{-1}$ DNA (background fluorescence), or $315 \mathrm{ng} \mathrm{ml}^{-1}$ DNA with either $\mathrm{H} 33258$ or EthDi. For excitation and emission scans, $100 \mu$ of each fluorochrome, or an equivalent volume of buffer, were added to a cuvette containing $2.3 \mathrm{ml}$ of either DNA or buffer. Final fluorochrome concentrations were $1.5 \times 10^{-7} \mathrm{M}$ H33258, $4.7 \times 10^{-7} \mathrm{M}$ EthDi, and $4.7 \times 10^{-7} \mathrm{M} \mathrm{EthBr}$.

Fluorescence measurements were made using a Perkin-Elmer MPF-66 fluorescence spectrophotometer. A rhodamine standard was used to calibrate the monochromators and normalize fluorescence. The excitation wavelengths, emission wavelengths and emission fil- ters for H33258 were EXWL $=350 \mathrm{~nm}, \mathrm{EMWL}=450$ $\mathrm{nm}$, and EMFILT $=430 \mathrm{~nm}$; for EthDi they were EXWL $=300 \mathrm{~nm}$, EMWL $=620 \mathrm{~nm}$, and EMFILT $=610 \mathrm{~nm}$. and for EthBr they were EXWL $=290 \mathrm{~nm}, \mathrm{EMWL}=600$ $\mathrm{nm}$, and EMFILT $=430 \mathrm{~nm}$. Excitation and emission slits were $20 \mathrm{~nm}$. The same parameters, where appropriate, were used for excitation and emission scans, except that the emission filter was set to $390 \mathrm{~nm}$ for all emission scans.

Natural samples. Natural seawater samples were collected, prepared, and analyzed on July 7, 1988 about $150 \mathrm{~km}$ off Pt. Reyes, California (37 $24.0^{\prime} \mathrm{N}, 124^{\circ}$ $23.3^{\prime} \mathrm{W}$ ) on RV 'Wecoma' during cruise 8806-B. This was a region of active upwelling and mixing of nearshore and offshore surface waters (Strub et al. 1991). Samples from 4 depths $(5,20,60,100 \mathrm{~m})$ were retrieved in 51 Niskin bottles fitted to a Neil-Brown CTD Rosette sampler. Depth profiles of $\sigma_{t}$ and total pigment (pigtot $=$ chl a and phaeopigments) were provided by Fleischbein et al. (1989). Samples were prefiltered through a $300 \mu \mathrm{m}$ screen, and pressure filtered in duplicate through a $1.0 \mu \mathrm{m}$ followed by a $0.2 \mu \mathrm{m}$ Nuclepore filter. Treatments and measurements were identical to those above except that (1) filters were sonicated in $5.05 \mathrm{ml}$ of buffer with $0.0025 \%$ Triton X-100, (2) RNA and DNA measurements were made by adding $100 \mu$ l of $\mathrm{H} 33258$ or EthDi to $1 \mathrm{ml}$ of blank, sample, or standard, (3) final fluorochrome concentrations were $1.5 \times 10^{-7}$ and $5.3 \times$ $10^{-7} \mathrm{M}$ for $\mathrm{H} 33258$ and EthDi respectively.

Nucleic acid calculations. The double fluorochrome method utilized H33258 to measure DNA (Eq. 1), and EthDi to measure the fluorescence of both DNA and RNA. RNA was calculated by first determining the amount of EthDi fluorescence due to DNA (Eq. 2), and
Fig. 1. Independent emission scans of $\mathrm{H} 33258$ at $1.5 \times 10^{-7} \mathrm{M}$ (curve 1 ) and EthDi at $4.7 \times 10^{-7} \mathrm{M}$ (curve 2) with $300 \mathrm{ng} \mathrm{ml}^{-1}$ of calf thymus DNA excited at $350 \mathrm{~nm}$ and 300 $\mathrm{nm}$ respectively The same scans of $\mathrm{H} 33258$ (curve 3) and EthDi (circles on curve 2) were also made with both fluorochromes in the same cuvette. Curve 4 is an emission scan of H33258 at $1.5 \times 10^{-7} \mathrm{M}$ without DNA. The response of curves 3 and 4 have been multiplied by a factor of 2. Curve 3 has been corrected by subtracting an emission scan of EthDi with DNA excited at $350 \mathrm{~nm}$

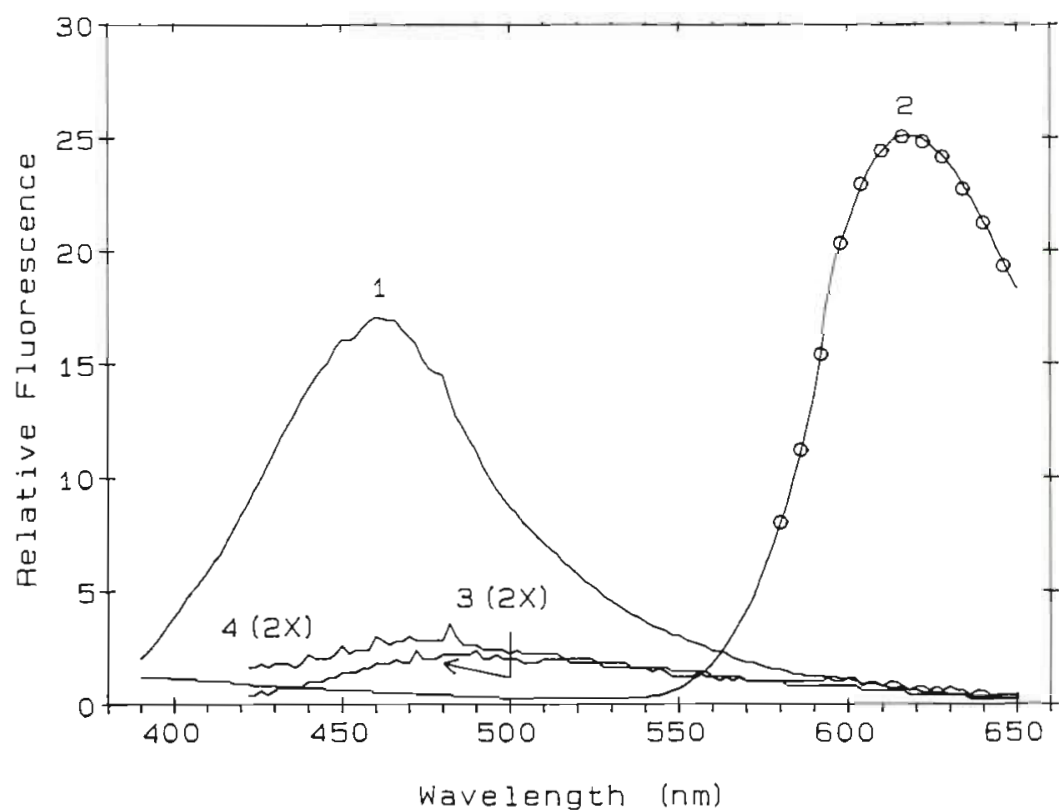


subtracting this from the total EthDi fluorescence (Eq. 3). The RNase digestion method utilized EthDi on 2 subsamples of the homogenate, one treated with RNase and a second free of added RNase. The first was used to measure DNA (Eq. 4) and the second to measure the fluorescence of both DNA and RNA. RNA calculations also involved subtracting the EthDi fluorescence due to DNA from the total EthDi fluorescence (Eq. 5). Three daily filter blanks for each treatment were averaged and subtracted from the corresponding homogenate fluorescence. The fluorochromenucleic acid standard responses used in the calculations were the averages from all daily measurements. Filtration and dilution corrections used in the nucleic acid calculations are not shown. Deviations were determined by propagating the standard error of the means of the filter blanks and standards (Bevington 1969).

\section{Double fluorochrome method using H33258 and} EthDi.

$$
\begin{aligned}
\text { DNA }= & \left(\text { Sample }_{\mathrm{H} 33258}-\text { Blank }_{\mathrm{H} 33258}\right) / \\
& \text { H33258 DNA Standard }
\end{aligned}
$$

EthDi $_{\text {DNA }}=$ DNA $\times$ EthDi DNA Standard

RNA $=\left(\right.$ Sample $_{\text {EthDi }}-$ Blank $k_{E t h D i}-E_{\text {thDi }}$ DNA $) /$ EthDi RNA Standard

RNase digestion method using EthDi.

$$
\begin{aligned}
\text { DNA }= & \left(\text { Sample }_{\text {RNase }}-\text { Blank }_{\text {RNase }}\right) / \\
& \text { EthDi DNA Standard } \\
\text { RNA }= & {\left[(\text { Sample }- \text { Blank })-\left(\text { Sample } \text { RNase }^{-}\right.\right.} \\
& \text {Blank } \left.\left.k_{\text {RNase }}\right)\right] / \text { EthDi RNA Standard }
\end{aligned}
$$

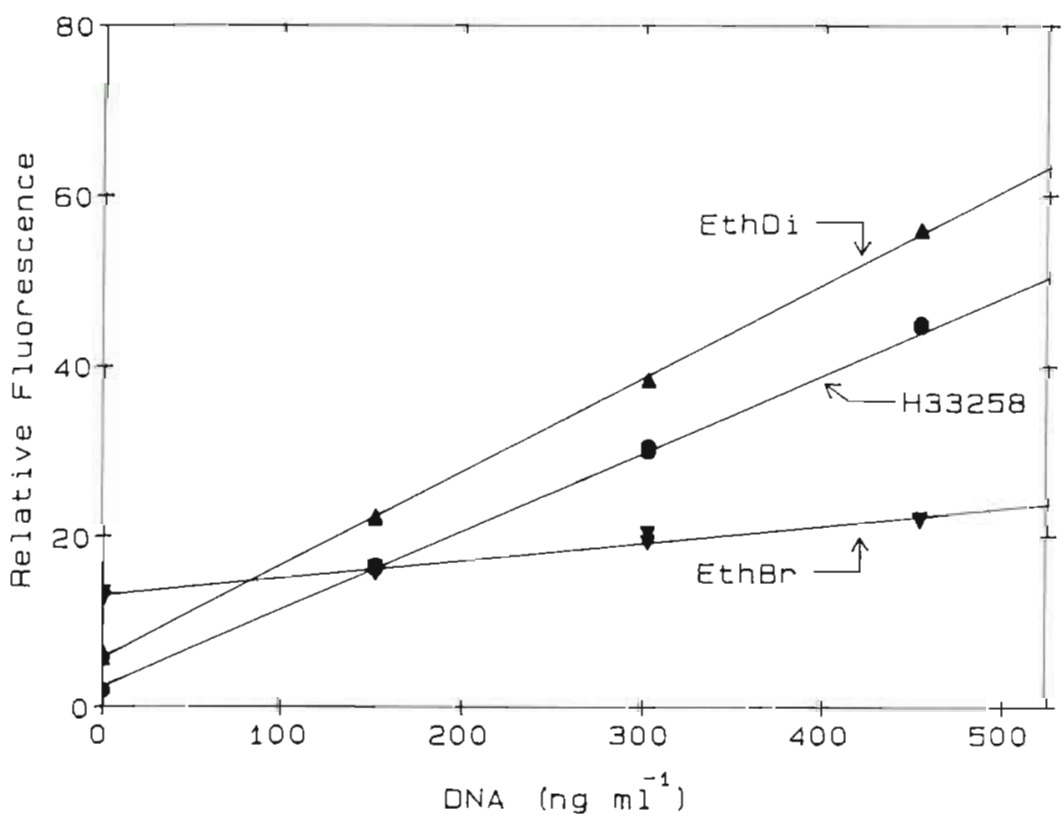

\section{RESULTS}

\section{DNA emission scans}

Fig. 1 shows emission scans for DNA with H33258 and EthDi. The emission peaks of H33258 (excited at $350 \mathrm{~nm}$ ) and EthDi (excited at $300 \mathrm{~nm}$ ) with standard DNA were at $460 \mathrm{~nm}$ and $617 \mathrm{~nm}$ respectively (curves 1 and 2). The fluorochromes were combined in a cuvette and measured independently. When combined, the EthDi DNA emission peak was unchanged (circles on curve 2), but the broad H33258 DNA emission peak was significantly reduced (curve 3). It was clear from these results that although DNA could be measured with EthDi in the presence of $\mathrm{H} 33258$, the converse was not true. (Curve 3 did contain an EthDi component above $550 \mathrm{~nm}$, and was corrected by subtracting a scan of EthDi with DNA excited at $350 \mathrm{~nm}$ ). Corrected or not, the $460 \mathrm{~nm}$ H33258 DNA emission peak (curve 1) was shifted by about $20 \mathrm{~nm}$ to $480 \mathrm{~nm}$ in the presence of EthDi (curve 3) and closely resembled the emission scan of unbound H33258 (curve 4). The reduction and shift of the H33258 fluorescence when EthDi was present may have resulted from the displacement of H33258 molecules from DNA by EthDi.

\section{Standard responses}

Three standards were regularly measured and used to calculate DNA and RNA in cultures and natural samples: DNA with EthDi, DNA with H33258, and Escherichia coli strain B RNA with EthDi. These standards had detection limits of 25,35 and $70 \mathrm{ng} \mathrm{ml}^{-1}$

Fig. 2. Response of ( 4 EthDi at $4.7 \times 10^{-7} \mathrm{M}$, (•) H33258 at $1.5 \times 10^{-7} \mathrm{M}$, and (v) EthBr at $4.7 \times 10^{-7} \mathrm{M}$ with calf thymus DNA. Replicate measurements were made at each concentration. The excitation wavelengths, emission wavelengths and emission filters were 350,450 and $430 \mathrm{~nm}$ for $\mathrm{H} 33258 ; 300$, 620 and $610 \mathrm{~nm}$ for EthDi; and 290,600 and $430 \mathrm{~nm}$ for EthBr, respectively. Excitation and emission slits were $20 \mathrm{~nm}$ 
Fig. 3. Response of EthDi at $4.7 \times 10^{-7} \mathrm{M}$ with different types and preparations of RNA. The dotted lines connect $(\Delta)$ average Escherichia coli strain W rRNA and $(\nabla)$ average bovine rRNA measurements. Single line connects average measurements of $(0) E$. coli strain W tRNA, () E. coli strain B RNA and $(+)$ yeast type III RNA. Symbols are indistinct due to similarities of RNA responses. Double line is a least squares fit of yeast type XI RNA measurements $(\diamond)$. Optical parameters for EthDi were the same as in Fig. 2

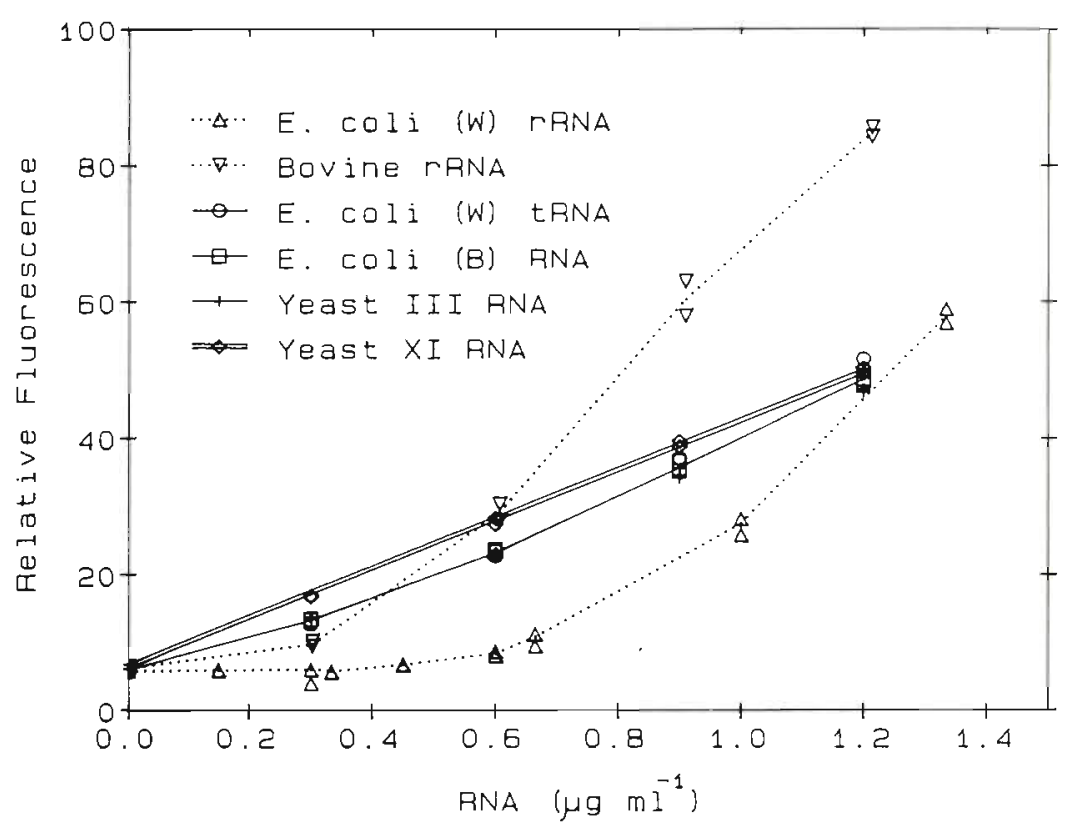

any fluorochrome-nucleic acid combination tested. (The RNA response of EthBr has been shown to be smaller than for DNA; Boer 1975.) Under our conditions, EthDi had a much lower blank and was more than 5 times more sensitive than EthBr. Therefore, replacing EthBr with EthDi significantly reduced the sample volume needed for nucleic acid determinations.

The response of several RNA standards with EthDi were also compared. EthDi had a linear response to yeast RNA type XI, a slightly non-linear response to several uncharacterized RNAs and tRNA, and a concave response to several rRNAs (Fig. 3). Escherichia coli strain B RNA and yeast RNA type III both showed
Fig. 4. Effect of chl $a$ on the fluorescence of (4) EthDi at $4.7 \times 10^{-7} \mathrm{M}$ and (•) H33258 at $1.5 \times 10^{-7} \mathrm{M}$ with $302 \mathrm{ng} \mathrm{ml}^{-1}$ of calf thymus DNA. Background fluorescence of chl a (without fluorochromes but with DNA) was also measured at the same wavelengths used for $(\Delta)$ EthDi and (o) H33258. The majority of EthDi blanks are concealed in the abscissa

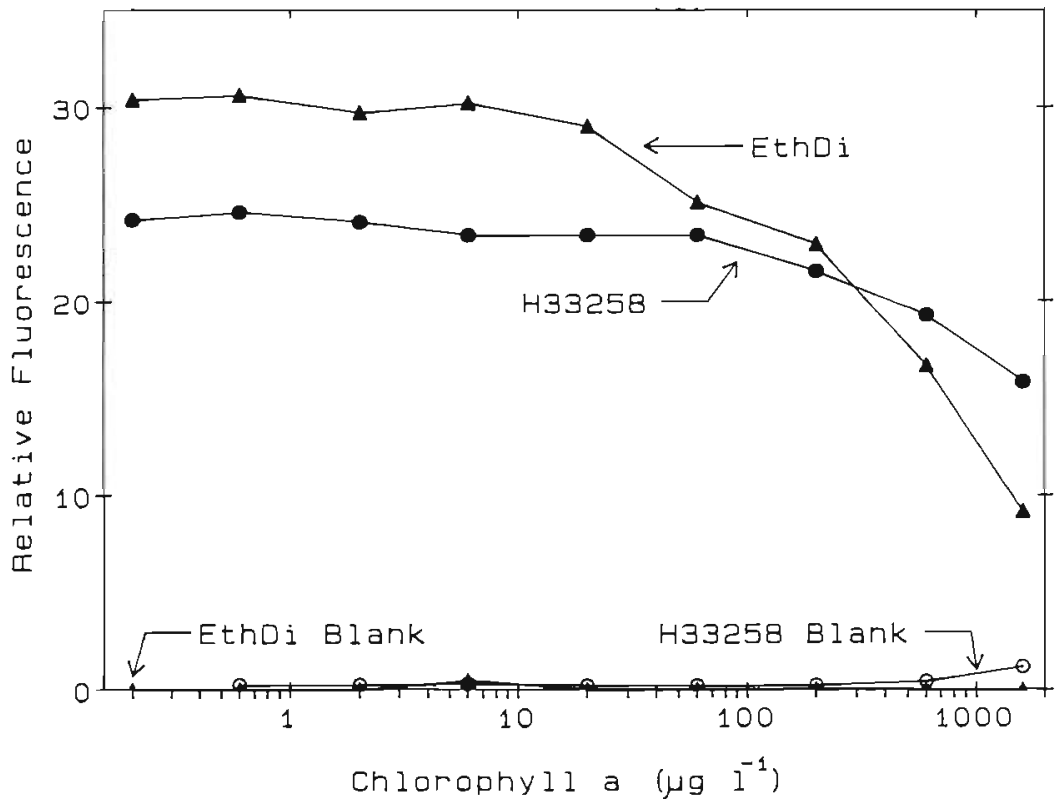


an EthDi response almost identical to purified tRNA, supporting the manufacturer's claims that these RNAs were predominantly tRNA. Also, the similarity between the EthDi response with yeast RNA type XI and tRNA suggested that yeast RNA type XI, thought by the manufacturer to include both tRNA and rRNA, contained a large proportion of tRNA. The EthDi response of 2 rRNA standards from different sources was similar in shape, but appeared to be offset by about $0.4 \mu \mathrm{g} \mathrm{ml}^{-1}$. E. coli strain W rRNA showed no fluorescence response at concentrations below $0.6 \mu \mathrm{g} \mathrm{ml}^{-1}$, but above $1.3 \mu \mathrm{g} \mathrm{ml}^{-1}$ the response was similar to that expected for tRNA. Bovine liver rRNA showed no response below $0.3 \mu \mathrm{g} \mathrm{ml}^{-1}$, but above $0.6 \mu \mathrm{g} \mathrm{ml}^{-1}$ the strongest response of any RNA was observed. Because the response of EthDi depended on the type of RNA, the choice of an RNA standard was critical for interpreting RNA concentrations. For example, a sample homogenate with low RNA concentrations may have been overestimated if referenced to an IRNA standard or underestimated if referenced to a tRNA standard. Finally, there was no fluorescence response of $E$. coli strain B RNA treated with RNase (not shown) which indicated that RNase digestions were complete.

\section{Chlorophyll a interierence}

In homogenates of natural samples prepared for the double fluorochrome method, chl a concentrations of $60 \mathrm{ug}^{-1}$ have been observed (unpubl.). The fluores-

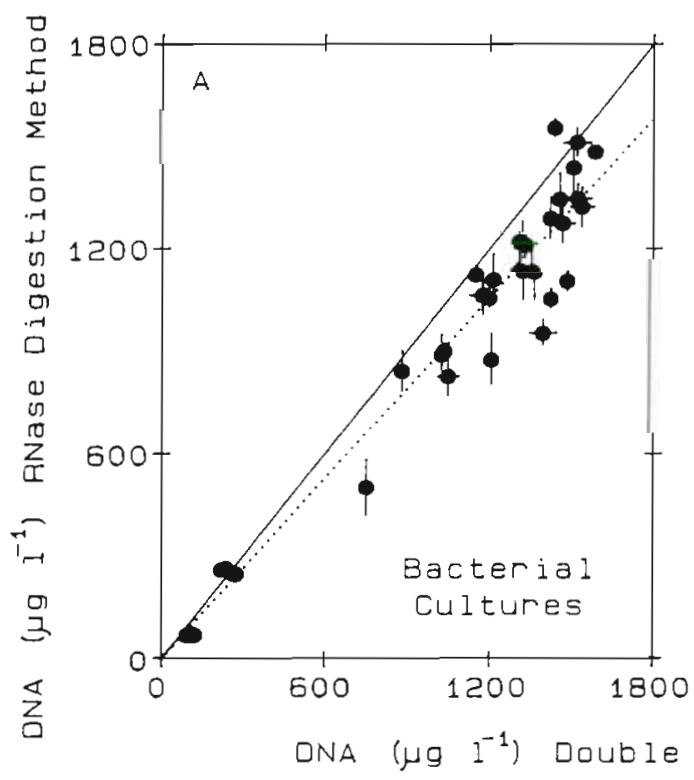

Fig. 5. Comparison of DNA measured with the double fluorochrome method and the RNase digestion method (A) on cultures of the marine bacteria OR5-88 at different stages of starvation survival, and (B) on batch cultures of phytoplankton. The

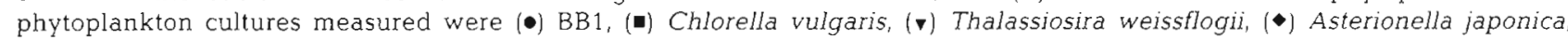
(4) Gymnodinium simplex, and (s) Chaetoceros sp. Solid lines indicate ideal fits, dotted line is the best fit through the origin of the bacterial measurements. Error bars indicate propagated standard errors of the blanks and standards cence of $\mathrm{H} 33258$ with standard DNA was independent of standard chl a concentrations below $60 \mu \mathrm{g} \mathrm{l} \mathrm{l}^{-1}$, but began to decrease at higher chl a concentrations with a $30 \%$ fluorescence loss at $1600 \mu \mathrm{I} \mathrm{l}^{-1} \mathrm{chl} \mathrm{a} \mathrm{(Fig.} \mathrm{4).} \mathrm{The}$ fluorescence of EthDi with DNA decreased when chl a concentrations were above $20 \mu \mathrm{g}^{-1}$ and was reduced $70 \%$ at concentrations of $1600 \mu \mathrm{g} \mathrm{l} \mathrm{l}^{-1}$. For homogenates with chl a concentrations above $20 \mu \mathrm{gl}^{-1}$, fluorescent quenching must be considered, especially with EthDi. The background fluorescence of chl a (measured with $302 \mathrm{ng} \mathrm{m}^{-1}$ DNA at $\mathrm{H} 33258$ and EthDi wavelengths without the presence of fluorochromes) was minimal, even at $1600 \mu \mathrm{g}^{-1}$. Therefore the influence of high pigment concentrations cannot be corrected by simply subtracting the background fluorescence of sample homogenates as suggested by Thoresen et al. (1983), but must include corrections for quenching of the sample fluorescence.

\section{Comparison of methods}

DNA measurements made with the double fluorochrome method and the RNase digestion method were compared using bacterial (Fig. 5A) and phytoplankton (Fig. 5B) cultures. Each replicate was plotted individually since much of the error between replicates was likely due to filtering small volumes ( 1 to $6 \mathrm{ml}$ ). (DNA in bacterial cultures of OR5-88 decreased over $121 \mathrm{~d}$ of starvation from about 1500 to $100 \mu \mathrm{g} \mathrm{l}^{-1}$. Details of the bacterial results in relation to starvation-survival will

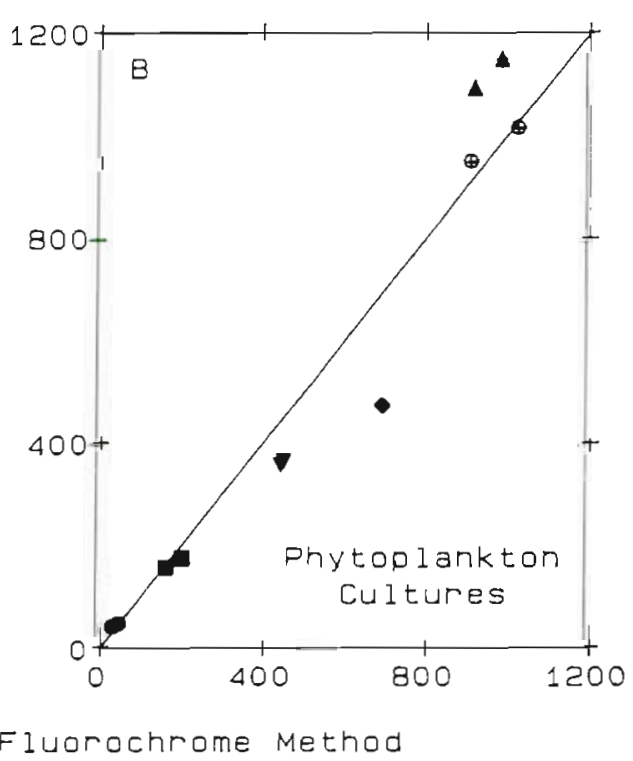


be discussed in a separate publication.) On average, DNA concentrations in cultures of OR5-88 were $12 \%$ higher when measured with the double fluorochrome method relative to the RNase digestion method. The specificity of $\mathrm{H} 33258$ for DNA rich in dA-dT base pairs (Weisblum \& Haenssler 1974, Comings 1975) may have caused this difference. Six phytoplankton cultures were also measured for DNA using both techniques (Fig. 5B). DNA concentrations for cultures of Chaetoceros sp. (900 to $\left.1000 \mu \mathrm{g}^{-1}\right)$, Chlorella vulgaris (150 to $200 \mu \mathrm{g} \mathrm{l}^{-1}$ ), and BB1 (30 to $50 \mu \mathrm{g} \mathrm{l}^{-1}$ ) were measured equally well by both techniques. Relative to the RNase digestion method, the double fluorochrome method resulted in higher DNA concentrations for Thalassiosira weissflogii (440 vs $360 \mu^{\prime} \mathrm{gl}^{-1}$ ) and Asterionella japonica (690 vs $470 \mathrm{\mu g} \mathrm{l}^{-1}$ ), and lower concentrations for Gymnodinium simplex (920 to 980 vs 1100 to $1150 \mu \mathrm{g} \mathrm{l}^{-1}$ ). Measurements on phytoplankton cultures were probably complicated by the base specificity of $\mathrm{H} 33258$ and by quenching and background fluorescence from pigments. Still, DNA was generally measured equally well for all cultures using either of the techniques, both of which were sensitive, simple, and fast, although the RNase digestion method required an extra digestion step.

Fig. 6 shows RNA measurements by both methods on the same cultures of bacteria (Fig. 6A) and phytoplankton (Fig. 6B) measured for DNA. Like bacterial DNA, the bacterial RNA concentration decreased with $121 \mathrm{~d}$ of starvation from 1000 to $1500 \mu \mathrm{g} \mathrm{l}^{-1}$ down to less than $100 \mu \mathrm{g} \mathrm{l}^{-1}$. Some values were less than zero, even when considering the range of standard errors. These measurements were assumed to be below detection limits of the techniques and were set equal to zero. The large

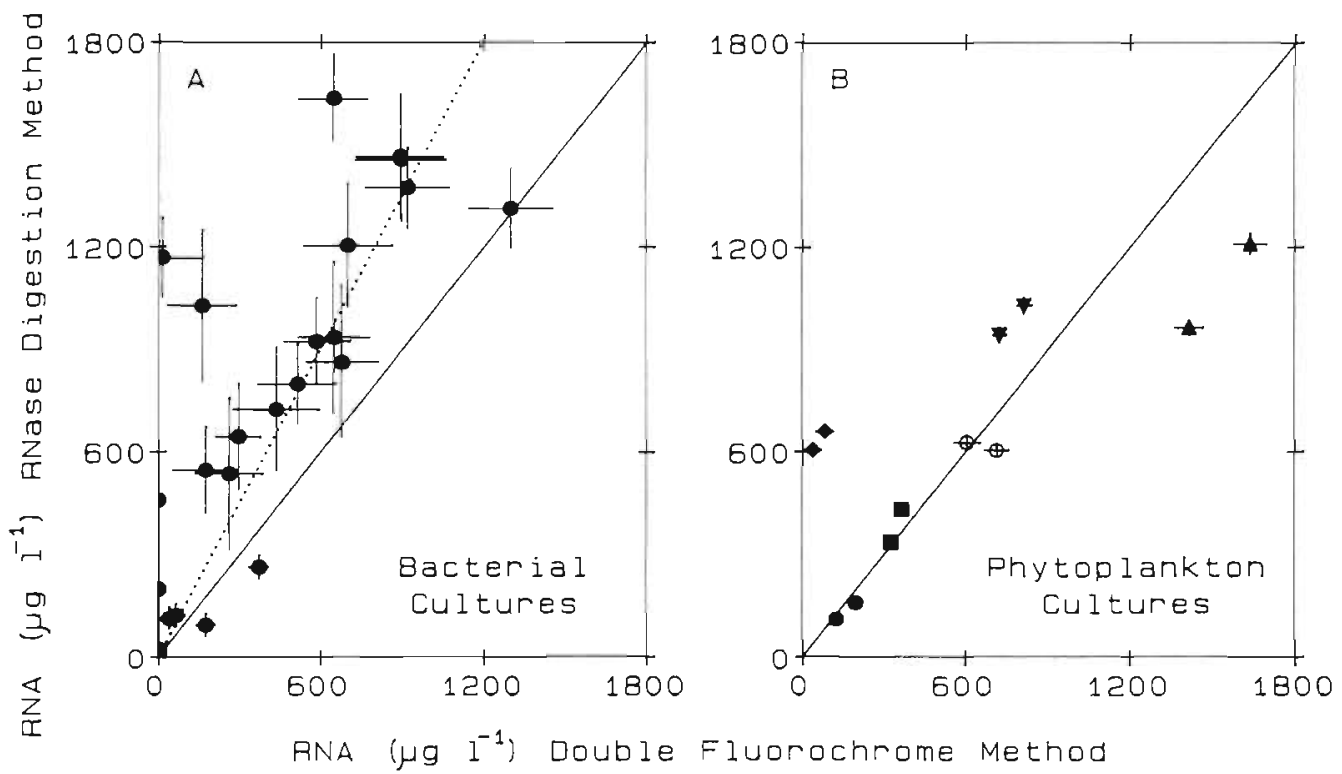

Fig. 6. RNA measurements on (A) marine bacteria and (B) phytoplankton cultures as in Fig. 5

\section{Natural samples}

uncertainties associated with bacterial RNA measurements were primarily due to variance in the filter blanks. RNA errors were also amplified by the number of steps necessary to propagate standard and blank SEMs. The 2 methods measured similar RNA concentrations on phytoplankton cultures of Chaetoceros sp. (600 to $\left.710 \mathrm{\mu g} \mathrm{l}^{-1}\right)$, Chlorella vulgaris (320 to $430 \mu \mathrm{g} \mathrm{l}^{-1}$ ), and BB1 (110 to $\left.190 \mu \mathrm{g} \mathrm{l}^{-1}\right)$, the same cultures for which both techniques measured equal amounts of DNA. For both methods, RNA is calculated by subtracting DNA from the same total fluorescence value, so this result is not unexpected. Asterionella japonica had an RNA value of about $600 \mu \mathrm{g} \mathrm{I}^{-1}$ with the RNase digestion method, but RNA was almost absent $\left(60 \mu \mathrm{g} \mathrm{l}^{-1}\right)$ using the double fluorochrome method. The RNase method also measured higher RNA relative to the double fluorochrome method for Thalassiosira weissflogii $(980$ $\mu \mathrm{g} \mathrm{l}^{-1}$ vs $870 \mu \mathrm{g} \mathrm{l}^{-1}$ ), but lower RNA for Gymnodinium simplex (950 to $1200 \mu \mathrm{g} \mathrm{l}^{-1}$ vs 1400 to $1600 \mu \mathrm{g} \mathrm{l}^{-1}$ ). Scatter about the ideal fit for RNA (Fig. 6) was much larger than for DNA (Fig. 5) due to the relatively lower sensitivity of EthDi for RNA.

Depth profiles of $\sigma_{t}$, pig $_{\text {tot, }}$ DNA and RNA/DNA were measured in natural waters (Fig. 7). The nucleic acid measurements were made on size fractionated $(>0.2$ $\mu \mathrm{m}$ but $<1.0 \mu \mathrm{m})$ samples using the double fluorochrome method. These results were part of a larger study to be described in a separate publication. This station had a mixed layer of about $20 \mathrm{~m}$ with $\sigma_{t}=24.9$ and pig tot $>1.0 \mu \mathrm{g} \mathrm{I}^{-1}$. From 25 to $100 \mathrm{~m}, \sigma_{\mathrm{t}}$ increased to 


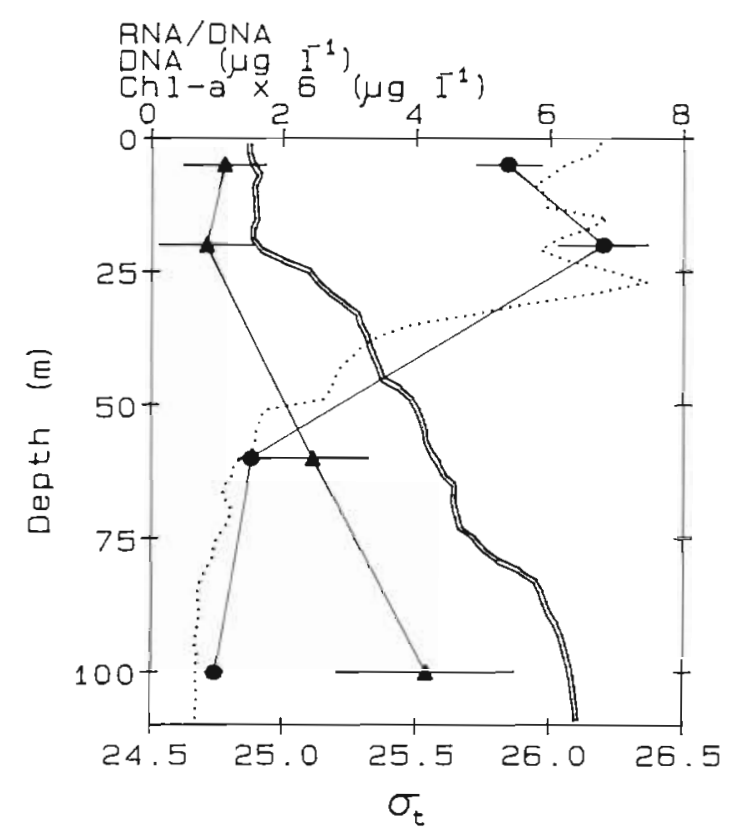

Fig. 7 Depth profiles of $\bullet$ DNA and (4) RNAJDNA in the $>0.2 \mu \mathrm{m}$ but $<1.0 \mu \mathrm{m}$ size fraction of natural seawater samples. Also shown are profiles of $\sigma_{t}$ (double line) and total pigment (chl a and phaeopigments; dotted line). Error bars indicate propagated standard errors of the standards, blanks, and replicate means

$>26.0$, and pig tot decreased to the detection limit of the instrument. DNA concentrations were 5 to $7 \mathrm{\mu g} \mathrm{l}^{-1}$ in the upper $20 \mathrm{~m}$ but dropped to 1 to $2 \mu \mathrm{g} \mathrm{l^{-1 }}$ at 60 to 100 $\mathrm{m}$, and RNA/DNA ratios increased with depth from about 1 near the surface to about 4 at $100 \mathrm{~m}$. The speed and simplicity of this technique allowed for preparation and analysis of these samples for DNA or RNA at sea in less than 10 min per replicate.

\section{DISCUSSION}

The emission peaks of H33258 and EthDi with standard DNA showed little overlap suggesting that these fluorochromes could be combined to measure RNA and DNA in a single cuvette simply by changing excitation and emission wavelengths. Unfortunately H33258 fluorescence with standard DNA disappeared in the presence of EthDi. EthDi had a small excitation peak at $530 \mathrm{~nm}$ (not shown) which could have absorbed H33258 fluorescence. EthDi may have displaced H33258 from DNA as suggested by a $20 \mathrm{~nm}$ shift in the diminished $\mathrm{H} 33258$ emission peak which corresponded to the free fluorochrome. Hoechst 33258 binds in the major groove on the outside of DNA double helices with a binding constant of about $10^{5} \mathrm{M}^{-1}$ (Comings 1975, Müller \& Gautier 1975) while EthDi at low ionic strength mono-intercalates with a binding constant of about $10^{8} \mathrm{M}^{-1}$ in $0.2 \mathrm{M} \mathrm{Na}^{+}$(Gaugain et al. $1978 \mathrm{~b}$, Delbarre et al. 1983). H33258 binding sites may have been blocked or disrupted by either the stronger binding of EthDi or simply from EthDi intercalation, which is known to elongate DNA (Berman \& Young 1981, Waring 1981). Because EthDi fluorescence was relatively unchanged in the presence of H33258, a double fluorochrome method could be used to determine DNA and RNA in a discrete cuvette or in a flow cytometer by first measuring H33258 then adding and measuring EthDi. Cuvettes must be cleaned after every measurement as any residual EthDi will compromise subsequent H33258 measurements.

It has been suggested that EthDi is 100 times more sensitive for DNA than EthBr (Markovits et al. 1979), but under our conditions the dimer was only about 5 times more sensitive. Still, Thoresen et al. (1983) found that EthBr measurements on phytoplankton samples required filtration of 1 to $5 \mathrm{l}$ of coastal seawater while the high sensitivity of $\mathrm{H} 33258$ and EthDi allowed us to measure DNA and RNA on as little as $25 \mathrm{ml}$ of surface water. Sample homogenates prepared for EthBr measurements also had high background fluorescence (fluorescence without EthBr) resulting from high pigment concentrations (Thoresen et al. 1983). Due to our smaller sampling volumes, chl a concentrations in over 100 natural sample homogenates prepared for EthDi and H33258 measurements were typically less than 20 $\mu \mathrm{gl}^{-1}$, but several were as high as $60 \mu \mathrm{g} \mathrm{l}^{-1}$ (unpubl.). Although minimal background fluorescence was observed for these natural sample homogenates and for standard chl $a$ at H33258 and EthDi wavelengths, Fig. 4 suggests that EthDi fluorescence was quenched at chl a concentrations above $20 \mu \mathrm{g} \mathrm{l}^{-1}$. Other cellular constituents might also interfere with the fluorescence of H33258 or EthDi. For example, in experiments similar to those in Fig. 4, phycoerythrin concentrations of 1000 $\mu \mathrm{g}^{-1}$ resulted in quenching and background fluorescence of EthDi, but not of H33258 (Baeuerle 1990). Also, phycocyanin showed little background fluorescence or quenching of EthDi at $1000 \mu \mathrm{g} \mathrm{l}^{-1}$ (Baeuerle 1990). As probably true with any nucleic acid stain, accurate measurements should include standard additions of DNA to quantify any fluorescence quenching (see Saxberg \& Kowalski 1979).

The phytoplankton and bacteria cultures used to compare DNA measurements made with the double fluorochrome method and the RNase digestion method represented a wide range of DNA concentrations and various stages of growth. DNA measurements by the 2 techniques were generally very similar. For some cultures significantly higher DNA values were observed for 1 of the 2 techniques. These discrepancies may have resulted from pigments or other cell constituents quenching or contributing background 
fluorescence to one of the fluorochromes, or from the known dependence of $\mathrm{H} 33258$ on the base composition of DNA. Fluorescence of H33258 is stronger with A.Trich DNA than with GC-rich DNA (Weisblum \& Haenssler 1974, Comings 1975). Therefore, variations in DNA measured with H33258 may have reflected changes in the base composition of the samples relative to a standard, in this case $60 \%(\mathrm{~A}+\mathrm{T})$ calf thymus DNA (Comings 1975). Unlike H33258, EthDi is not sensitive to base compositions of natural DNA (Markovits et al. 1979). Therefore, if the double fluorochrome and RNase digestion techniques are both used to measure DNA of a sample, the ratio of the 2 measurements can be used to estimate the base composition of that sample. Data from Weisblum \& Haenssler (1974) and Comings (1975) was used to develop a relationship between the ratio of DNA Double Fluorochrome / DNA RNase Digestion and the mole fraction $(A+T)$. Our bacterial culture OR5-88, which should have had minimal background and quenching complications, had a DNA Double Fluorochrome / DNA RNase Digestion ratio of 1.14 which corresponded to 70 to $75 \%(A+T)$. Similar calculations were made with Gymnodinium simplex (45 to $50 \% \mathrm{~A}+\mathrm{T}$ ) and Asterionella japonica (100 to $125 \% \mathrm{~A}+\mathrm{T}$ ). The DNA base compositions of the bacterial cultures and $G$. simplex were in the range observed for many types of organisms: 30 to $70 \%(\mathrm{~A}+\mathrm{T})$ (Green 1974, Comings 1975, Müller \& Gautier 1975). In contrast, EthDi quenching or a large background fluorescence at H33258 wavelengths must have occurred in samples of A. japonica. Because of the dependency of H33258 on base composition, the RNase digestion method should be used when measuring pure cultures, each of which has a specific base composition. On natural samples, accuracy of the double fluorochrome method improves, because as the variety of organisms increases, the mole fraction $(\mathrm{A}+\mathrm{T})$ should approach $50 \%$.

To measure RNA, a proper RNA standard must be chosen. Selecting an RNA standard is complicated because the response of EthDi differs for tRNA and rRNA, the 2 major components of cellular RNA. Concentrations below $300 \mathrm{ng} \mathrm{ml^{-1 }}$ of rRNA could not be detected, yet, depending on the organism and growth conditions, 80 to $90 \%$ of cellular RNA is rRNA, with the remainder being mostly tRNA (Darnell 1968, Lewin 1974). Uncharacterized Escherichia coli strain B RNA, thought to be mostly tRNA (see 'Results'), was the standard used for our samples, but because low concentrations of rRNA could not be measured, RNA measurements were considered as minimal concentrations. The varying standard responses may have been due to changes in excitation or emmision spectra. Berdalet \& Dortch (pers. comm.) observed such changes for different RNA standards, and with different lots of the same standard. RNA measurements were further complicated because the extent of intercalation may have varied between standard RNA and cellular RNA. Proteins are bound to the bulk of cellular RNA and may alter (increase or decrease) intercalation; intercalation of several tRNAs is known to change upon the formation of a tRNA-protein complex (Ferguson \& Yang 1986, Kuznetsova et al. 1987). When protein-free RNA standards are used, the proteins in natural samples should be digested or otherwise efficiently removed from RNA (see Karsten \& Wollenberger 1977). Using samples untreated for proteins and whole ribosomes as an RNA standard may prove a simpler and more accurate procedure, especially with bacterial samples free of nucleohistones.

The non-linear responses observed for all but one of the RNA standards might reflect conformational changes in RNA with increasing concentration. Because the RNA helix must elongate or alter its conformation to accept an intercalator (Berman \& Young 1981, Waring 1981), changes in tertiary structure which alter the flexibility of RNA also affect intercalation (Reinhardt et al. 1982, White \& Draper 1989). For example, intercalation of EthBr with phenylalanine specific tRNA ( $\left(R N A^{\text {Phe) }}\right.$ ) has been shown to be limited to one or several binding sites under conditions which stabilize the tRNA ${ }^{\text {Phe }}$ tertiary structure (Tao et al. 1970, Urbanke et al. 1973, Kean et al. 1985). Therefore, if RNA tertiary structure was modified with increasing RNA concentration, either the number of EthDi binding sites in RNA or the affinity of EthDi at a particular binding site may have been altered. However any relationships between changes in RNA tertiary structure and RNA concentration remain unclear. In naked RNA, tertiary structure could have been modified by nonspecific RNA aggregation (Boedtker 1968). Whatever the causes of the non-linear RNA standard curves, yeast RNA type XI was not affected.

Response curves for the 2 rRNAs with EthDi had the same general shape but were separated by about $0.4 \mu \mathrm{g}$ $\mathrm{ml}^{-1}$. This offset may have been caused by difficulties in determining the actual concentration of rRNA, RNA base specificity of EthDi, or preferential binding of EthDi to bovine liver rRNA due to tertiary constraints as discussed above. Concentrations of rRNAs were not determined gravimetrically but by the UV absorbance to weight conversions provided by the manufacturer. The accuracy of these conversions was not determined, and deviations could explain variability in the standard curves. (The standards may have been partially digested by nucleases during commercial preparation.) Also, if EthDi binding sites are limited in certain RNA types or preparations, then comparing standards based on weight would not be valid. The units $\mu \mathrm{gl}^{-1}$ were used because neither the molecular weights nor the number of binding sites per molecule for the various RNAs was 
known. Finally, both EthBr and EthDi are specific for poly(A-U) over other synthetic polyribonucleotides, especially poly(G-C) (Markovits et al. 1979, Babayan et al. 1987). Although the base specificity of a fluorochrome with synthetic polynucleotides does not necessarily inply an analogous preference in natural samples (Markovits et al. 1979), such specificity might explain the differences between rRNAs if the mole fraction $(A+U)$ was higher for bovine liver rRNA binding sites.

Although bacterial RNA concentrations were considerably higher using the RNase digestion method (Fig. $6 \mathrm{~A})$, for most measurements this discrepancy disappeared if DNA values were corrected for an estimated $70 \% \mathrm{dA}$-dT base composition. Several bacterial samples resulted in RNA values less than zero even when considering the range of their standard errors. Several factors may have contributed to these negative numbers. On these days the EthDi filter blanks (measured with fluorochromes but without sample) were high relative to other days and relative to $\mathrm{H} 33258$ and RNase treated filter blanks. Subtraction of high blanks from the total EthDi fluorescence would have resulted in low RNA measurements. Also, all but one of these samples occurred after $15 \mathrm{~d}$ of starvation. Cellular RNA may have been catabolized during starvation to an extent that homogenate RNA concentrations were lower than the detection limit of the method.

Phytoplankton RNA measurements were always detectable. The low RNA concentrations of Asterionella japonica with the double fluorochrome method were probably related to $E$ th $D i$ quenching relative to H33258 as mentioned above. High RNA/DNA ratios were observed for batch cultures of BB1 and Chlorella vulgaris and low RNA/DNA ratios were found for Chaetoceros sp. and Gynodinium simplex. Although not the focus of this study, the concentrations and ratios of nucleic acids are very likely related to the ages of the cultures. High RNA/DNA ratios may have been from young cultures with a small number of rapidly-growing cells, while low RNA/DNA ratios may have been measured in older cultures containing many slow growing cells in a nutrient-depleted medium (Dortch et al. 1983).

Depth profiles of DNA and the RNA/DNA ratio measured in the 0.2 to $1.0 \mu \mathrm{m}$ size fraction of natural seawater using the double fluorochrome technique (Fig. 7) demonstrated the usefulness and sensitivity of this method. A simple explanation of the data could be that there were a relatively large population of bacterial size organisms (Paul \& Carlson 1984) near the surface with relatively low growth rates, and fewer organisms with higher growth rates at 50 and $100 \mathrm{~m}$. This assumes that DNA is a conservative measure of biomass and RNA/DNA increases with metabolic activity. Differences with depth in growth rates might be caused by changes in nutrients (DOM) whereas differences in standing stock might be a result of more grazing at 50 to $100 \mathrm{~m}$. The RNA/DNA profile might also be influenced by an increasing tRNA/rRNA ratio in natural populations with depth.

We have demonstrated the use of 2 techniques to measure DNA and RNA in the marine environment, both of which are sensitive, simple and rapid, but subject to some qualifications. These techniques can provide data to help understand population dynamics of marine plankton. Using H33258 and EthDi together and without nucleases to measure nucleic acids may be especially useful because the technique could be the basis of a flow cytometric system for whole seawater. Such a system might include a flow-through filter and sonicator to isolate and disrupt desired size fractions of organisms and 2 lasers or a split-beam laser with 2 detectors to excite and measure both $\mathrm{H} 33258$ and EthDi.

Acknowledgements. Thanks to Dr Henry W Schaup, Brigitte Baeuerle, Laurent Mezin, Kaijun Lin and the crew of the RV 'Wecoma' for advice and assistance. Support for part of this work came from the Office of Naval Research under contract number N00014-87-K-0242.

\section{LITERATURE CITED}

Babayan, Y., Manzini, G., Xodo, L. E., Quadrifoglio, F. (1987). Base specificity in the interaction of ethidium with synthetic polyribonucleotides. Nucleic Acids Res. 15: 5803-5812

Baeuerle, B. G. (1990). Isolation, extraction, and fluorometric measurements of nucleic acids and DNA photorepair in marine macrophytes. M.S. thesis, Oregon State University

Berman, H. M, Young, P. R. (1981). The interaction of intercalating drugs with nucleic acids. A. Rev. Biophys. Bioeng 10: $87-114$

Bevington, P. R. (1969). Data reduction and error analysis for the physical sciences. McGraw-Hill, New York

Boedtker, H. (1968). Molecular weight and conformation of RNA. In: Grossman, L., Moldave, K. (eds.) Methods in enzymology, Vol XII. Academic Press, London, 429-458

Boer, G. J. (1975). A simplified microassay of DNA and RNA using ethidium bromide. Analyt. Biochem. 65:225-231

Bonaly, J., Bre, M. H., Lefort-Tran, M., Mestre, J. C. (1987). A flow cytometric study of DNA staining in situ in exponentially growing and stationary Euglena gracilis. Cytometry 8: $42-45$

Clemmesen, C. (1988). A RNA and DNA fluorescence technique to evaluate the nutritional condition of individual marine fish larvae. Meeresforsch. 32: 134-143

Comings, D. E. (1975). Mechanisms of chromosome banding VIII. Hoechst 33258-DNA interaction. Chromosoma 52 $229-243$

Darnell, J. E. (1968). Ribonucleic acids from animal cells. Bact. Rev. 32: 262-290

Delbarre, A., Gourevitch, M. I., Gaugain, B., Le Pecq, J. B., Roques, B. P. (1983). ${ }^{1} \mathrm{H}$ NMR study of an ethidium dimer poly $(\mathrm{dA}-\mathrm{dT})$ complex: evidence of a transition between bis and monointercalation. Nucleic Acids Res. 11.4467-4482

Dortch, Q., Roberts, T L., Clayton, J. R., Jr, Ahmed, S. I (1983). RNA/DNA ratios and DNA concentrations as indi- 
cators of growth rate and biomass in planktonic marine organisms. Mar. Ecol. Prog. Ser 13: 61-71

Eppley, R. W., Holmes, R. W., Strickland, J. D. H. (1967). Sinking rates of marine phytoplankton measured with a fluorometer. J. exp mar Biol. Ecol. 1: 191-208

Ferguson, B. Q., Yang, D. C. H. (1986). Localization of noncovalently bound ethidium in free and methionyl-tRNA synthetase bound tRNA ${ }^{\text {iMet }}$ by singlet-singlet energy transfer Biochemistry 25: 5298-5304

Fleischbein, J., Schramm, R. S., Huyer, A., Kosro, P. M., Cowles, T., Krefft, K., Paulson, C. (1989). CTD observations in the coastal transition zone off Northern California from R/V Wecoma, July to August 1988. Data Report 144, Ref. 89-1. College of Oceanography, Oregon State University

Gaugain, B., Barbet, J., Oberlin, R., Roques, B. P., Le Pecq, J. B. (1978a). DNA bifunctional intercalators. 1. Synthesis and conformational properties of an ethidium homodimer and of an acridine ethidium heterodimer. Biochemistry 17 : $5071-5078$

Gaugain, B., Barbet, J., Capelle, N., Roques, B. P., Le Pecq, J. B. (1978b). DNA bifunctional intercalators. 2. Fluorescence properties and DNA binding interaction of an ethidium homodimer and an acridine ethidium heterodimer. Biochemistry 17: 5078-5088

Green, B. R. (1974). Nucleic acids and their metabolism. In: Stewart, W. D. P. (ed.) Algal physiology and biochemistry. University of California, Berkeley, p. 281-313

Iturriaga, R., Mitchell, B. G., Kiefer, D. A. (1984). Assay of RNA and DNA in microalgae with a front face fluorometer Arch. Hydrobiol. Beih. Ergebn. Limnol. 19: 101-107

Karsten, U., Wollenberger, A. (1977). Improvements in the ethidium bromide method for direct fluorometric estimation of DNA and RNA in cell and tissue homogenates. Analyt. Biochem. 77: 464-470

Kean, J. M., White, S. A., Draper, D. E. (1985). Detection of high-affinity intercalator sites in a ribosomal RNA fragment by the affinity cleavage intercalator methidiumpropyl-EDTA-Iron(II). Biochemistry 24: 5062-5070

Kuznetsova, N. V., Borisova, O. F., Morozov, I. A., Gambaryan, A. S., Venkstern, T V (1987). Complexing of tRNA (adenine-1-)-methyltransferase from Thermus thermophilus HB8 with tRNA studied by utilizing ethidium bromide fluorescence. Mol. Biol. 21. 420-429 (English transl.) Soviet J. mar. Biol.

Lewin, B. (1974). Gene expression, Vol. 1, Bacterial genomes. Wiley and Sons, New York

Markovits, J., Roques. N. P., Le Pecq, J. B. (1979). Ethidium dimer a new reagent for the fluorimetric determination of nucleic acids. Analyt. Biochem. 94: 259-264

Moyer, C. L., Mordy, C. W., Carlson, D. J., Morita, R. V. (1990). Ethidium homodimer used for the sensitive measurement of DNA and RNA of a psychrophilic marine bacterium grown at different growth rates during starvation-survival. J. microbiol. Meth. 12: 75-81

This article was submitted to the editor
Moyer, C.L., Morita, R. Y (1989). Effect of growth rate and starvation-survival on the viability and stability of a psychrophilic marine bacterium. Appl. environ. Microbiol. 55: 1122-1127

Müller, W., Gautier, F. (1975). Interactions of heteroaromatic compounds with nucleic acids: A-T specific non-intercalating DNA ligands. Eur. J. Biochem. 54: 385-394

Paul, J. H., Carlson, D. J. (1984). Genetic material in the marine environment: implication for bacterial DNA. Limnol. Oceanogr. 29: 1091-1097

Paul, J. H., Jeffrey, W. H., Deflaun, M. (1985). Particulate DNA in subtropical oceanic and estuarine planktonic environments. Mar. Biol. 90: 95-101

Paul, J. H., Myers, B. (1982). Florometric determination of DNA in aquatic microorganisms by use of Hoechst 33258. Appl. environ. Microbiol 43: 1393-1399

Randerath, K., Randerath, E. (1969). Analysis of nucleic acid derivatives at the subnanomole level; III. A tritium labeling procedure for quantitative analysis of ribose derivatives. Analyt. Biochem. 28: 110-118

Reinhardt, C. G., Roques, B. P., Le Pecq, J. B. (1982). Binding of bifunctional ethidium intercalators to transfer RNA. Biochem. biophys. Res. Commun. 104: 1376-1385

Saxberg, B. E. H., Kowalski, B. R. (1979). Generalized standard addition method. Analyt. Chem. 51: 1031-1038

Strub, P. T., CTZ group (1991). The nature of the cold filaments in the California current system. J. Geophys. Res. (in press)

Takahashi, M., Nagai, H., Yamaguchi, Y., Ichimura, S. (1974). The distribution of chlorophyll a, protein, RNA and DNA in the North Pacific Ocean. J. oceanogr. Soc. Japan 30 : $137-150$

Tao, T., Nelson, J. H., Cantor, C. R. (1970). Conformational studies on transfer ribonucleic acid. Fluorescence lifetime and nanosecond depolarization measurements on bound ethidium bromide. Biochemistry 9: 3514-3524

Thoresen, S. S., Clayton, J. R. Jr, Dortch, Q., Ahmed, S. I. (1983). A rapid technique for the determination of RNA and DNA in marine phytoplankton. J. Plankton Res. 5: $253-261$

Urbanke, C., Römer, R, Maass, G. (1973). The binding of ethidium bromide to different conformations of tRNA; unfolding of tertiary structure. Eur J. Biochem. 33: 511-516

Waring, M. J. (1981). DNA modification and cancer. A. Rev. Biochem. 50: 159-192

Weisblum, B., Haenssler, E. (1974). Fluorometric properties of the bibenzimidazole derivative Hoechst 33258, a fluorescent probe specific for AT concentration in chromosomal DNA. Chromosoma 46: 255-260

White, S. A., Draper, D. E. (1989). Effects of single-base bulges on intercalator binding to small RNA and DNA hairpins and a ribosomal RNA fragment. Biochemistry 28: $1892-1897$

Manuscript first received: August 13, 1990

Revised version accepted: February 11, 1991 